EDUKACJA FILOZOFICZNA

VOL. 652018

JOANNA BUDKE

Katolicki Uniwersytet Lubelski Jana Pawła II
ARTYKUŁY I ROZPRAWY

doi: 10.14394/edufil.2018.0003

\title{
WYCHOWANIE W LOGOTERAPII VIKTORA EMILA FRANKLA
}

Viktor Emil Frankl znany jest jako twórca logoterapii, koncepcji psychoterapii, która łączy psychologię z m.in. filozofią egzystencjalną, fenomenologią i filozofią dialogu. W centrum logoterapii stawia się człowieka rozumianego jako jedność biologiczno-psychiczno-duchowa. Frankl upatruje istoty człowieka w jego warstwie duchowej, dzięki której może odnosić się on do świata sensu i wartości. W książce Was nicht in meinen Büchern steht pisze: „Tematem przewodnim wszystkich moich prac jest wyjaśnienie granic obszaru leżącego pomiędzy psychoterapią a filozofią, ze specjalnym odniesieniem do problemu sensu i wartości"'. Wyjście z płaszczyzny badań typowych dla psychoterapii ku zagadnieniom filozoficznym wydaje się charakteryzować naukowe zainteresowania Frankla i ma swoje odzwierciedlenie w dwóch terminach: „logoterapii” ${ }^{2}$ i „logoteorii”’3, którymi określa opracowaną przez siebie koncepcję psychoterapii. Kategorie te wspólnie nawiązują do greckiego słowa „logos”, znaczącego tyle co „sens” i „duch”. Frankl wskazuje, że „logoterapia, lub jak to jest określane przez niektórych autorów, trzecia wiedeńska szkoła psychoterapii, skupia się zarówno na sensie ludzkiej egzystencji, jak rów-

\footnotetext{
V. E. Frankl, Was nicht in meinen Büchern steht, Quintessenz MMV Medizin Verlag, München 1995, s. 39-40.

2 Tenże, Man's Search for Meaning: an Introduction to Logotherapy, Washington Square Press, New York 1964 s. 160.

3 Tamże.

4 Tamże.
} 
nież na człowieku poszukującym tego sensu"5. Do pedagogiki logoterapia została zaadaptowana niejako wtórnie przez takich autorów jak Karl Dienelt $^{6}$, Franz Schlederer ${ }^{7}$, Beda Wicki ${ }^{8}$, Eva Maria Waibel ${ }^{9}$. Dienelt np. jest przekonany, że tylko pedagogika dobrze ugruntowana $\mathrm{w}$ antropologii filozoficznej może dojść do rzetelnego poglądu na temat celu wychowania i przedstawia logoterapię jako propozycję dla tego rodzaju pedagogicznego fundamentu ${ }^{10}$. Na grunt nauki polskiej trzecia wiedeńska szkoła psychoterapii została zaszczepiona przez ucznia Frankla - Kazimierza Popielskiego ${ }^{11}$. Warto wspomnieć, że w Polsce do logoterapeutycznej problematyki wychowania rozwiniętej przez Eugenia Fizzottiego ${ }^{12}$ i Carla Nanniego ${ }^{13}$ nawiązują m.in. Jarosław Tomasz Michalski ${ }^{14}$ i Marian Nowak $^{15}$.

Logoterapia - jak wskazuje Frankl - ma charakter wychowawczy ${ }^{16}$ osadzony na odniesieniu jednostki ludzkiej do świata sensu i wartości.

Tamże, s. 153-154.

6 K. Dienelt, Erziehung zur Verantwortlichkeit. Die Existenzanalyse V. E. Frankls und ihre Bedeutung für die Erziehung, Österreichischer Bundesverlag, Wien 1955.

$7 \quad$ F. Schlederer, Erziehung zu personaler Existenz. Viktor E. Frankl's Existenzanalyse und Logotherapie als Beitrag zu einer anthropologisch fundierten Pädagogik, Viktor E. Frankl's Existenzanalyse und Logotherapie als Beitrag zu einer anthropologisch fundierten Pädagogik, Inaugural-Dissertation, München 1964, s. 2.

8 B. Wicki, Die Existenzanalyse von Viktor E. Frankl als Beitrag zu einer anthropologisch fundierten Pädagogik, Verlag Paul Haupt, Bern-Stuttgart 1991, s. 199-202.

9 E. M. Waibel, Erziehung zum Sinn - Sinn der Erziehung. Grundlagen einer existenziellen Pädagogik, Brigg Pädagogik Verlag, Augsburg 2011.

10 K. Dienelt, Erziehung zur Verantwortlichkeit. Die Existenzanalyse V. E. Frankls und ihre Bedeutung für die Erziehung. dz. cyt., s. 22.

11 K. Popielski, Psychologia egzystencji. Wartości wżyciu człowieka, Wydawnictwo Katolickiego Uniwersytetu Lubelskiego, Lublin 2008.

12 E. Fizzotti, La logoterapia di Frankl. Un antidoto alla disumanizzazione psicanalitica, Rizzoli, Milano 1974.

13 C. Nanni, Educazione e scienze dell'educazione, LAS, Roma 1986.

14 J. T. Michalski, Sens życia a pedagogika. Impulsy życia V. E. Frankla, Wydawnictwo Naukowe Uniwersytetu Mikołaja Kopernika, Torun 2011.

15 M. Nowak, Znaczenie wartości w procesie wychowania, w: K. Popielski (red.), Człowiekwartości-sens. Studia z psychologii egzystencji. Logoteoria i nooteoria. Logoterapia i nooterapia, Redakcja Wydawnictw Katolickiego Uniwersytetu Lubelskiego, Lublin 1996, s. 241-259.

16 V. E. Frankl, Nieuświadomiony Bóg, Instytut Wydawniczy PAX, Warszawa 1978, s. 93-94. 
Nie chodzi jednak o skuteczne nauczenie człowieka „ekonomii sensu”, aby przy minimalnym wysiłku uczynić swoje życie jak najbardziej sensownym. W logoterapii pragnie się podkreślić, że sens nie jest czymś, co można „wytworzyć”, ani czymś, na co można „zapracować”. Frank1 wskazuje na istotne rozróżnienie pomiędzy terminami: „sens” i „sukces"17. Człowiek często rozpatruje swoje wybory na osi pomiędzy dwoma skrajnymi punktami: „sukcesem” i - jego negatywnym odpowiednikiem - „porażką”. Jednak, czy osiągnięcie sukcesu finansowego, w biznesie lub w karierze zawodowej, można utożsamić z poczuciem sensowności życia?

Nierzadko ludzie sukcesu, stojący na szczycie, jak np. piosenkarze, pisarze, politycy, popełniają samobójstwo. Z kolei ludzie żyjący na skraju ubóstwa lub pracujący w organizacjach charytatywnych - a więc w miejscach niewiążących się raczej z korzyściami finansowymi i możliwością kariery zawodowej - niejednokrotnie mają poczucie największego osobistego spełnienia. Życie pełne sensu może być zarówno życiem pełnym sukcesu, jak i niepowodzenia - i odwrotnie: brak poczucia sensu może ujawniać się w życiowym powodzeniu lub niepowodzeniu. Przeżycia sensu jednak nie da się sprowadzić do przeżycia sukcesu.

Frankl proponuje, aby porzucić perspektywę utylitarnej arytmetyki „zysków i strat” na drodze prowadzącej do sukcesu i przyjąć spojrzenie zorientowane na działania osoby w pespektywie sensu. Jeżeli człowiek zmaga się z poczuciem ,bezsensowności” życia, to nie dlatego, że sens nie istnieje. Sens istnieje, jako coś jedynego i specyficznego, odnoszącego się do konkretnej osoby znajdującej się w określonej sytuacji życiowej ${ }^{18}$. Sens może dla „tej-oto-osoby” w danych okolicznościach miejsca i czasu pozostawać zakryty i zadaniem Franklowskiej psychoterapii jest pomóc pacjentowi uświadomić sobie jego istnienie. Celem wychowawczym Frankla jest uzdolnienie człowieka do odkrywania jego unikalnego sensu ${ }^{19}$. Wychowawczy imperatyw logoterapii osiąga swój najwyższy

17 Tenże, The Unheard Cry for Meaning. Psychotherapy and Humanism, A Touchstone Book, New York 1979, s. 41-43.

18 Tenże, Psychotherapy and Existentialism. Selected Papers on Logotherapy, Souvenir Press, London 1970, s. 57.

19 Tenże, The Will to Meaning. Foundations and Applications of Logotherapy, New America 
stopień w uświadomieniu jednostki ludzkiej o spoczywającej na niej odpowiedzialności za odkryty sens ${ }^{20}$, dlatego Frankl określa swoje podejście również „wychowaniem do odpowiedzialności" ${ }^{21}$. Podobnie problematykę wychowawczą wokół fenomenu odpowiedzialności sytuuje chociażby Martin Buber ${ }^{22}$. Proces wychowawczy w logoterapii można rozumieć jako towarzyszenie pacjentowi w jego osobowym dojrzewaniu dokonującym się poprzez przyjęcie postawy odpowiedzialności za realizowany sens, który nie może być jakimkolwiek sensem, ale powinien być sensem obiektywnym, sensem odkrytym, sensem „na miarę” realizującej go osoby.

\section{Wychowanie jako fakt międzyosobowy}

Frankl - podobnie jak Tadeusz Gadacz ${ }^{23}$ - fenomen wychowania sytuuje w przestrzeni międzyosobowej. Najbardziej efektywne zmiany wychowawcze w pacjencie nie dokonują się w wyniku zastosowania wyuczonych przez terapeutę technik, ale w rezultacie spotkania drugiej osoby $^{24}$. Teresa Kukułowicz stwierdza, że „wychowanie to działalność, której ostateczny cel wyraża się w pomocy człowiekowi w usprawnianiu i realizacji życia, którego kształt będzie wypełnieniem jest zasadniczego sensu" "25, jednak jak sama przyznaje, błędem byłoby oczekiwać, że to sensy lub wartości „wychowują”. Wychowywać może tylko osoba.

„Wychowanie jest wychowaniem do bycia osobą"26 - zauważa Gadacz. Frankl - podobnie jak Buber ${ }^{27}$ - określa wychowanie relacją dialo-

Library, New York-London-Scarborough, Ontario 1970, s. 64.

20 Por. K. Dienelt, Die anthropologischen Grundlagen der Pädagogik. Konstruktiv-analytische Reflexionen zum Thema „Pädagogische Anthropologie”, A. Henn Verlag, Kastellaun-Düsseldorf 1977, s. 147.

21 V. E. Frankl, Psychoterapia dla każdego, Instytut Wydawniczy PAX, Warszawa 1978, s. 154.

22 M. Buber, Wychowanie, „Znak” 1968, nr 166, s. 446.

23 T. Gadacz, Wychowanie jako spotkanie osób, „Znak” 1991, nr 436, s. 62-68.

24 V. E. Frankl, Psychotherapy and Existentialism. Selected Papers on Logotherapy, dz. cyt., s. 78.

25 T. Kukułowicz, Wartości w wychowaniu, w: K. Popielski (red.), Człowiek-wartości-sens. Studia z psychologii egzystencji. Logoteoria i nooteoria- Logoterapia i nooterapia, dz. cyt., s. 411.

26 T. Gadacz, Wychowanie jako spotkanie osób, dz. cyt., s. 63.

27 M. Buber, Wychowanie, dz. cyt., s. 458. 
gową. Logoterapeutyczne wychowanie opiera się na osobowym spotkaniu terapeuty i pacjenta ${ }^{28}$. Ważny jest element osobowego oddziaływania terapeuty-wychowawcy jako czynnik wpływający na wewnętrzne dojrzewanie pacjenta-ucznia. Na pytanie ,jak działać jako osoba?” trudno uzyskać teoretyczną odpowiedź, prawdę tę poznaje się poprzez osobiste świadectwo i własne doświadczenie życiowe. Proces wychowania w logoterapii nie jest procesem naprawiania popsutego mechanizmu aparatu, $\mathrm{z}$ którym utożsamiany jest pacjent. Psychoterapeuta nie „naprawia”, lecz raczej apeluje do pacjenta, oddziałując na całą jego osobę, aby uzdolnić go do samodzielnego zmagania się z sensem i wzięcia za ten sens odpowiedzialności. Ten apel realizuje się przez życiowy przykład logoterapeuty, który pociąga $\mathrm{w}$ ten sposób pacjenta $\mathrm{w}$ kierunku realizowania wartości. Terapeuta wskazuje, że sens może być osiągnięty, o czym zaświadcza swoim życiem, a zaświadczać może tylko ten, kto w to, co głosi, sam wierzy.

Gadacz, odnosząc się do rozróżnienia Gabriela Marcela ${ }^{29}$ pomiędzy „być a mieć”, kontrastuje ze sobą wychowanie w optyce „bycia osobą” z wychowaniem w optyce „funkcjonowania"30. Bytowanie człowieka na poziomie „funkcjonowania” rozumiane jest jako bycie nieosobowe. Poprzez uczestnictwo w wartościach i ich urzeczywistnianiu człowiek wzmacnia osobowy czynnik swojego bytu ${ }^{31}$. Na określenie człowieka bytującego na osobowym poziomie Frankl stosuje termin ,homo humanus"32, natomiast ,homunkulusem”33 nazywa człowieka degradującego swój osobowy wymiar do ,spełniania” funkcji biologiczno-psychicznych.

Elisabeth Lukas wskazuje, że Franklowski opis człowieka dotyczy napięcia pomiędzy tym, co immanentne, a tym, co transcendentne ${ }^{34}$. Immanencja wiąże się z ,wewnątrzświatowością bycia”, tam są rozpozna-

\footnotetext{
28 V. E. Frankl, Psychotherapy and Existentialism. Selected Papers on Logotherapy, dz. cyt., s. $81-82$.

29 G. Marcel, Być i mieć, Instytut Wydawniczy PAX, Warszawa 1986.

30 T. Gadacz, Wychowanie jako spotkanie osób, dz. cyt., s. 63.

31 Tamże.

32 V. E. Frankl, Homo patiens, Instytut Wydawniczy PAX, Warszawa 1984, s. 156.

33 Tamże, s. 294.

34 E. Lukas, Ein psychiatrisches und ein psychotherapeutisches Credo, w: D. Batthyány, O. Zsok (Hrsg.), Viktor Frankl und die Philosophie, dz. cyt., s. 13.
} 
wane i doświadczane: przestrzeń, czas, materia, przyczynowość ${ }^{35}$. To, co transcendentne, wiąże się z kolei z „,zewnątrzświatowością bycia”, z tym, co osobowe, co dotyczy wolności ${ }^{36}$. Człowiek dzięki wolności może przekraczać to, co „tutaj i teraz”: swój organizm psychofizyczny i to, co dane w naturze ${ }^{37}$. Centralną pozycję ,ja" w ludzkim bycie, pomiędzy światem natury i światem wolności, pozwala osiągnąć odpowiedzialność. Spotkanie osób staje się możliwe, kiedy człowiek otwiera się na świat i wychodzi „poza siebie” ku innym osobowym bytom, dzieje się to dzięki ludzkiej zdolności do przekraczania siebie, którą Frankl nazywa „autotranscendencją" 38 . Spotkanie pomiędzy osobami jest z kolei utrudnione, kiedy człowiek pozostaje zamknięty w swojej immanencji i bytuje niczym „monada" 39 .

\section{Samorealizacja a autotranscendencja}

Ludzkie działanie opiera się według Frankla na noodynamice ${ }^{40}$, tj. napięciu, które tworzy się pomiędzy osobą a światem wartości. Dynamikę działania człowieka we Franklowskiej psychoterapii wiąże więc z polem napięcia, gdzie na jednym skrajnym punkcie obecny jest czekający na wypełnienie sens, a na drugim skraju - człowiek, który stoi przed wyzwaniem, aby ten sens wypełnić ${ }^{41}$. Na wypełnienie sensu decyduje się człowiek w wolności i w poczuciu odpowiedzialności, rozstrzyga o tym sam, sam się otwiera bądź zamyka wobec świata wartości. W logoterapii pacjent jest konfrontowany z sensami i wartościami i jest zachęcany do ich wypełniania.

Warto podkreślić, że zarówno brak napięcia spowodowany utratą sensu jest niebezpieczny dla zdrowia psychicznego, jak i napięcie zbyt wysokie. Człowiek potrzebuje pewnej dawki zmagania się z wezwaniem

\footnotetext{
Tamże, s. 13-17.

Tamże, s. 14.

Tamże, s. 20.

38 V. E. Frankl, Psychotherapy and Existentialism. Selected Papers on Logotherapy, dz. cyt.,

39 Tamże, s. 38.

40 Tamże, s. 49.

$41 \quad$ Tenże, Man's Search for Meaning. An Introduction to Logotherapy, dz. cyt., s. 166.
} s. 74. 
płynącym od sensu czekającego na wypełnienie, z żądaniem stawianym człowiekowi przez sens ${ }^{42}$. Noodynamika jest dążeniem do czegoś, co nie zostało jeszcze osiągnięte, przez to oznacza, że wychowanie jest procesem stałym: wychowanie nigdy nie może być zadaniem w pełni ukończonym $^{43}$. Jak stwierdza Frankl: trzeba dążyć do absolutnego optimum, jeśli chce się osiągnąć względne optimum $\mathrm{w}$ danej sytuacji ${ }^{44}$, a bycie $\mathrm{w}$ ciągłym napięciu, które jest podstawą noodynamiki, jest konieczne dla osobowego dojrzewania ${ }^{45}$. Natomiast logoterapeutyczne wychowanie dąży do aktywacji duchowej przez skierowanie człowieka na sens i wartości ${ }^{46}$.

Franklowska koncepcja noodynamiki, idea, że człowiek znajduje się w ciągłym napięciu, które wynika z jego poszukiwania sensu, przeciwstawia się przekonaniu, że człowiek poszukuje tylko stanu psychicznej „równowagi" 47 . Dążenie do wewnętrznego equilibrium ${ }^{48}$ jest charakterystyczne dla „człowieka-monady” - osoby, która w swoim działaniu nie sięga ,poza siebie” - nie wykracza ku sensowi i wartościom, „w ten sposób nie jest zorientowana ku światu, lecz interesuje się wyłącznie sama sobą"49. Zachowanie „człowieka-monady” jest regulowane zasadą homeostatyczną: utrzymania bądź odzyskania stanu wewnętrznej równowagi, modelu pierwotnie zaczerpniętego z biologii ${ }^{50}$. Celem aktywności człowieka opartej na modelu homeostatycznym jest osiągnięcie ostatecznego „wewnętrznego bezruchu”; unikanie wewnętrznego napięcia, które wynika z naturalnej dynamiki bytowania wobec świata wartości i sensu, Frank1 określa jako „stan patologiczny" ${ }^{51}$.

\footnotetext{
$42 \quad$ Tenże, Psychotherapy and Existentialism. Selected Papers on Logotherapy, dz. cyt., s. 21.

43 Tenże, Der Mensch vor der Frage nach dem Sinn. Eine Auswahl aus dem Gesamtwerk, Piper, München-Zürich 1995, s. 217.

44 Tenże, Homo patiens, dz. cyt., s. 44.

45 Tamże, s. 45.

46 F. Schlederer, Erziehung zu personaler Existenz. Viktor E. Frankl's Existenzanalyse und Logotherapie als Beitrag zu einer anthropologisch fundierten Pädagogik, dz. cyt., s. 360.

47 V. E. Frankl, Der leidende Mensch. Anthropologische Grundlagen der Psychotherapie, Hans Huber, Bern 1975, s. 66.

48 Tenże, Psychotherapy and Existentialism. Selected Papers on Logotherapy, dz. cyt., s. 38.

49 Tenże, Homo patiens, dz. cyt., s. 148.

50 Tenże, Man's Search for Meaning. An Introduction to Logotherapy, dz. cyt., s. 166.

51 Tenże, Das Menschenbild der Seelenheilkunde. Kritik des dynamischen Psychologismus, Hip-
} 
Omawiana na gruncie logoterapii wola sensu, w przekonaniu Joanny Trzópek, bywa czasem błędnie rozumiana jako dążenie do samorealiza$\mathrm{cji}^{52}$. Franklowi nie chodzi jednak o realizację własnego ,ja”, ale o wypełnienie sensu. Wychowanie może prowadzić do rozwoju pacjenta, o ile jest wynikiem autotranscendencji ${ }^{53}$. Człowiek staje się bardziej „człowieczy”, kiedy zapomina o sobie, a nie kiedy koncentruje się na sobie samym ${ }^{54}$. Autotranscendencja opiera się na wykraczaniu poza ,ja" ku obiektywnemu sensowi i wartościom. Sens nie jest wytwarzany, ale odkrywany. Dążenie do samorealizacji jest zaprzeczeniem idei autotranscendencji, ponieważ człowiek zamyka się w kręgu siebie samego ${ }^{55}$. Zarówno realizacja siebie, jak i dążenie do przyjemności czy szczęścia nie powinny być bezpośrednimi celami ludzkiego działania: umykają one człowiekowi w tym samym stopniu, w jakim próbuje on do nich dążyćs ${ }^{56}$. Zjawiska te same w sobie nie są czymś złym, ale nie powinno się za nimi ,gonić” (im bardziej czyni się je przedmiotem swoich dążeń, tym bardziej się ich chybia ${ }^{57}$ ). Szczęście, przyjemność stanowią raczej skutek uboczny autotranscendencji, kiedy przekracza się siebie i przyjmuje się postawę służenia sensowi. Człowiek nastawia się na poszukiwanie przyjemności, szczęścia, kiedy zawodzi w życiu jego wola sensu's8; jednostka ludzka, zdaniem Frankla, pierwotnie zorientowana jest na dążenie ku sensowi ${ }^{59}$. Szczęście, przyjemność, jeżeli obiera się je za bezpośredni cel działania, stają się jedynie imitacją sensu ${ }^{60}$. W tym względzie nie można traktować świata sensu i wartości i płynącego od nich wezwania jako zwyklej samoekspresji. Przyjemność

\footnotetext{
pokrates Verlag, Stuttgart 1959, s. 15.

52 J. Trzópek, Problem woli. Między antropologia filozoficzną a psychologia mechanizmów regulacyjnych, Towarzystwo Naukowe Societas Vistulana, Kraków 2003, s. 150.

53 V. E. Frank1, Nieuświadomiony Bóg, dz. cyt., s. 105.

54 Tamże, s. 106.

55 Tenże, The Will to Meaning. Foundations and Applications of Logotherapy, dz. cyt., s. 38.

56 Tenże, Das Menschenbild der Seelenheilkunde. Drei Vorlesungen zur Kritik des dynamischen Psychologismus, dz. cyt., s. 58.

57 Tenże, Nieuświadomiony Bóg, dz. cyt., s. 112.

58 Tenże, Psychoterapia dla każdego, dz. cyt., s. 147.

59 Tamże, s. 148.

60 Tenże, The Will to Meaning. Foundations and Applications of Logotherapy, dz. cyt., s. 36.
} 
nie może być celem, a jedynie niezamierzonym efektem działania ${ }^{61}$; o ile ujawnia się to w sposób spontaniczny po wypełnieniu sensu lub zrealizowaniu wartości ${ }^{62}$. Jeżeli człowiek próbuje osiągnąć przyjemność, czyniąc z niej swój cel, chybi tego, w co celował ${ }^{63}$. Podobnie jest z ,pościgiem za szczęściem”: im bardziej dąży się do szczęścia, tym mniejsza jest szansa jego osiągnięcia ${ }^{64}$.

„Człowiek-monada” w stosunku do świata uprawia coś, co Frankl nazywa „kalejdoskopową epistemologią"65: ktoś, kto spogląda w kalejdoskop, nie widzi prawdziwego świata, lecz dostrzega tylko pewną konstelację różnych kolorowych kawałków szkła, które stanowią cześć kalejdoskopu ${ }^{66}$. Człowiek spoglądający przez kalejdoskop nie będzie w stanie nigdy sięgnąć do rzeczywistego świata. Jego świat nie jest niczym więcej niż projektem konstruowanym przez niego i odzwierciadlającym strukturę jego bycia. Tak jak kalejdoskopowy obserwator polega na małych kawałkach szkła, które zostały wrzucone do kalejdoskopu, tak też „kalejdoskopowa epistemologia" prezentuje tylko świat projektu, który całkowicie zależy od konstruującego go człowieka - jest zwykłym odbiciem jego subiektywnej kondycji i struktury. Subiektywizm nie dostrzega tego, że człowiek jest zdolny do zapominania o sobie, do wychodzenia ,poza siebie”. „Prawdziwe” bytowanie nie dotyczy samoekspresji, lecz autotranscendencji ${ }^{67}$. Człowiek albo transcenduje siebie i wychodzi do świata, albo uprawia „kalejdoskopię"68. Subiektywizm staje się niebezpieczny, ponieważ zapewnia ludziom ,złudne” poczucie spokoju, które wydaje się pożądane z perspektywy psychologicznej, ale ostatecznie będzie prowadziło do znudzenia i obojętności ${ }^{69}$ - właściwości przypisywanych przez

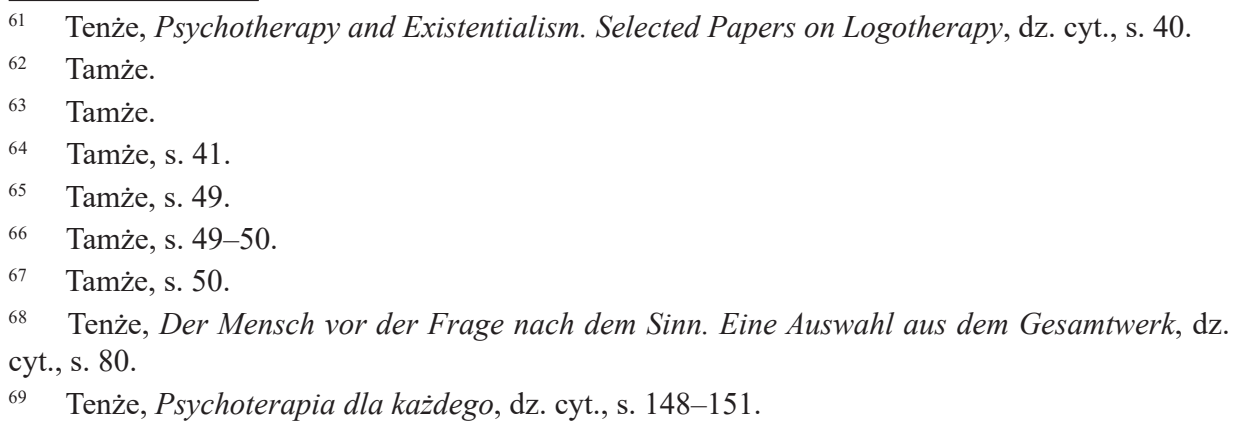


Frankla „próżni egzystencjalnej”, którą można pokonać, tylko budząc wolę sensu u pacjenta ${ }^{70}$.

Wobec zagrożenia subiektywizmem Frankl proponuje, aby zmienić perspektywę pytania o sens życia i dokonać ,przewrotu kopernikańskiego"71. Trzeba „uświadomić sobie, że to my mamy odpowiadać, a nie pytać, i że samo życie jest pytaniem. Pytanie, na które możemy odpowiedzieć w ten sposób, że za życie nasze przyjmujemy odpowiedzialność"72. Subiektywizm jest niebezpieczny, dlatego że samo posiadanie przez człowieka sensu życia nie jest wystarczające. Ten sens może być sensem „fałszywym”, do czego dochodzi zawsze, kiedy człowiek tworzy ten sens samodzielnie, bez „wychodzenia” do rzeczywistego świata ${ }^{73}$.

Franklowi nie chodzi również, jak zauważa Andrzej Szostek, o ,podsuwanie «choremu na bezsens» jakichkolwiek wartości, byle wyrwać go z przygnębienia $\mathrm{i}$ "pocieszyć»" "74. Celem wychowania w logoterapii będzie otwieranie pacjenta na świat sensu i wartości. Zdaniem Wolickiego we Franklowskiej psychoterapii można wskazać na otwartość bytu ludzkiego $\mathrm{w}$ rozumieniu horyzontalnym i wertykalnym ${ }^{75}$. Otwieranie na sens jako rzeczywistość obiektywną, a nie produkt psychiki, do stopnia otwartości na sens absolutny.

Otwartość na sens jest związana również z otwartością na pewien układ zdarzeń w świecie, który jest wyzwaniem i zadaniem dla człowieka i które tylko on może wypełniać. Logoterapeutyczne wychowanie będzie polegało nie tylko na pomocy pacjentowi w otwieraniu się na świat obiektywnego sensu i wartości, lecz także na wskazaniu różnicy pomiędzy realizacją prawdziwego sensu, a realizacją sensów fałszywych. Wy-

\footnotetext{
70 Tenże, Der Mensch vor der Frage nach dem Sinn. Eine Auswahl aus dem Gesamtwerk, dz. cyt., s. 229.

71 Tenże, Nieuświadomiony Bóg, dz. cyt., s. 99

72 Tenże, Homo patiens, dz. cyt., s. 126.

73 A. Längle, Orientierung am Sinn. Die unbedingte Suche nach Sinn, w: tegoż (Hrsg.), Wege zum Sinn. Logotherapie als Orientierungshilfe, Piper, München-Zürich 1985, s. 83.

74 A. Szostek, Człowiek-wartości-sens. Przemówienie na otwarcie IV Ogólnopolskiego Sympozjum Logoterapii w: K. Popielski (red.), Człowiek-wartości-sens. Studia z psychologii egzystencji. Logoteoria i nooteoria. Logoterapia i nooterapia, dz. cyt., s. 12.

75 M. Wolicki, Otwartość osoby ludzkiej. Interpretacja filozoficzna, Papieski Wydział Teologiczny we Wrocławiu, Wrocław 2005, s. 63.
} 
odrębniania prawdziwego sensu nie należy utożsamiać ze wskazywaniem pacjentowi konkretnych sensów i wartości do urzeczywistniania ${ }^{76}$. Kiedy pacjent odkrywa różne możliwości wypełniania sensów, jego zadaniem jest odnalezienie możliwe najwyższego sensu. Każdy człowiek, w każdym momencie może mieć tylko jedno zadanie do wypełnienia. Sens nieustanie się zmienia, z godziny na godzinę, z sytuacji na sytuację, ale nigdy nie przestaje zupełnie istnieć. Odpowiedź udzielana przez człowieka na pytanie o sens życia musi być odpowiedzią konkretną i aktywną, odpowiedzią w czynie ${ }^{77}$. Sens jest ukryty w każdej sytuacji, ale najbardziej staje się widoczny w sytuacjach granicznych, kiedy osoba zmaga się $\mathrm{z}$ cierpieniem, winą, śmiercią.

W logoterapii to sumienie jest traktowane jako „organ sensu”, którego zadaniem jest ,tropienie” sensu w świecie. Wychowanie będzie nie tylko polegać na przekazywaniu wiedzy, ale też ,swe przeznaczenie zasadnicze musi upatrywać w oczyszczaniu jednostkowego sumienia, tej jedynej władzy w jednostce, zdolnej do znajdowania sensu"78.

W logoterapii stosuje się kryterium ,,autentyczność - nieautentyczność", kiedy pragnie się wskazać, które pierwiastki dominują w działaniach człowieka: czy te ze sfery duchowej (autentyczność), czy te z poziomu biologiczno-psychicznego (nieautentyczność). Warto zaznaczyć, że nie chodzi tu o jakiś rachunek arytmetyczny, lecz raczej o „kierunek” bytowania: „od siebie”, jako wyraz autotranscendencji, czy „ku sobie”, jako wyraz immanencji. W przekonaniu Wojciecha Chudego termin ,autentyczność” jest pojęciem znaczeniowo niejasnym, staje się wręcz „mitem" wyrosłym na gruncie filozofii egzystencjalnej ${ }^{79}$.

Autentyczność, która ujawnia w dążeniach do zachowań absolutnie niezdeterminowanych, jest tak naprawdę autentycznością ugruntowaną

\footnotetext{
76 V. E. Frankl, The Will to Meaning. Foundations and Applications of Logotherapy, dz. cyt., s. 66 .

77 Tenże, Nieuświadomiony Bóg, dz. cyt., s. 12.

78 Tamże, s. 150.

79 W. Chudy, Prawda człowieka i prawda o człowieku, w: K. Popielski (red.), Człowiek-wartości-sens. Studia z psychologii egzystencji. Logoteoria i nooteoria. Logoterapia i nooterapia, dz. cyt., s. 134.
} 
w pustce ${ }^{80}$. Frankl wskazuje, że zadaniem logoterapeuty jest demaskowanie nieautentycznych postaw pacjenta, a przykład takiej rozmowy prowadzącej do odkrycia tłumionej rozpaczy pacjentki podany jest w pracy Nieuświadomiony Bóg ${ }^{81}$. Celem ,demaskowania” jest umożliwienie pacjentowi zwrócenie się w kierunku tego, co w nim autentyczne, czego kryterium odnajduje się w przynależności do wymiaru duchowego. Być autentycznym to nadawać nadrzędną rangę duchowości w stosunku do sfery biologiczno-psychicznej, oznacza panowanie duchowości w stosunku do sfery popędowej bytu ludzkiego ${ }^{82}$. Nieautentyczne będzie więc wszelkie poddanie popędom, czynnikom determinującym, dlatego autentyczność zaczyna się tam, gdzie rodzi się odpowiedzialność ${ }^{83}$. Być autentycznym to dla Frankla nic innego, jak być bytem odpowiedzialnym.

Bycie osobowe realizuje się w logoterapii poprzez uczestnictwo w wartościach: od wartości najniższej do najwyższej, którą Frankl nazywa Nad-osobą lub Nad-sensem. We Franklowskiej psychoterapii, odniesienie człowieka do Nad-osoby staje się gwarantem harmonijnej relacji osoby do świata. Uczestniczenie w wartościach - w tym w wartości najwyższej - umożliwia człowiekowi zachowanie osobowej więzi ze światem. Ten świat odsłania się poprzez spotkanie osób. Bez odniesienia do Nad-osoby człowiek jedynie używa rzeczy. W monadologicznym spojrzeniu na człowieka nie ma miejsca ani na prawdziwe spotkanie osób, ani na miłość ${ }^{84}$. W świecie „człowieka-monady” inne osoby traktuje się jako praktyczne narzędzia dla zachowania stanu homeostazy ${ }^{85}$. Nie ma miejsca na zobowiązanie płynące od wartości czy od innej osoby, ludzie są sprowadzani do poziomu zwykłych środków służących przywracania odpowiednich warunków w systemie psychicznym podmiotu. Jako ludzie wydają się nie mieć „,wartości w sobie”, lecz jedynie taki czy inny użytek ${ }^{86}$.

\footnotetext{
Tamże.

V. E. Frank1, Nieuświadomiony Bóg, dz. cyt., s. 101-103.

Tamże, s. 16.

Tamże, s. 16-17.

Tenże, Psychotherapy and Existentialism. Selected Papers on Logotherapy, dz. cyt., s. 38.

Tamże, s. 38-39.

Tamże, s. 39.
} 
W logoterapii wskazuje się przede wszystkim na funkcję spotkania pacjenta i logoterapeuty, czego wyrazem jest komunikacja egzystencjalna ${ }^{87}$, tylko między osobami może dojść do dialogu, tylko osoba do drugiej osoby może zwrócić się „ty”88. Logoterapeutyczne wychowanie jest spotkaniem osób: logoterapeuty jako mistrza i pacjenta jako ucznia; takie spotkanie otwiera przed pacjentem horyzont wartości, dzięki którym człowiek staje się człowiekiem. Logoterapeuta daje pacjentowi „przykład egzystencjalny, przykład osobistego zaangażowania w poszukiwanie prawdy. Rzeczywiście, odpowiedzi na pytanie, jaki jest sens życia,

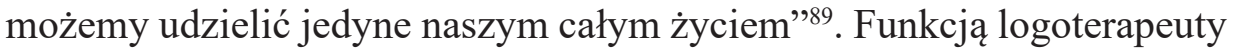
jest odsłanianie świata wartości i apelowanie do pacjenta. Sama osoba logoterapeuty stanowi wezwanie, na które pacjent odpowiada swoją wolną odpowiedzią, może odpowiedzieć albo „tak”, albo „nie”, aby podążać za logoterapeutą ku wartościom najwyższym. Logoterapeuta jest świadkiem wartości, a jego relacja z pacjentem jest oparta na niesieniu pomocy. Dla logoterapeuty każda osoba jest indywidualnością, a każda chwila jest czymś odmiennym, każdy pacjent i każde z nim spotkanie jest wyjątkowe i niepowtarzalne.

Frankl podkreśla, że dla pacjenta poddanego procesowi terapeutycznemu „uzdrawiająca” jest przede wszystkim relacja z psychoterapeutą, natomiast same techniki terapeutyczne pełnią funkcję niejako wtórną, pogłębiającą proces, który dokonuje się dzięki osobowej więzi pacjenta i terapeuty ${ }^{90}$. Zmiana w pacjencie jest inicjowana niejako przez terapeutę, przyjmowaną przez niego osobistą postawę, a nie przez repertuar technik terapeutycznych, których stosowaniem umie się wykazać. Logoterapeutyczny proces wychowawczy najprędzej dokona się, kiedy związek pacjenta i psychoterapeuty stanie się autentycznym spotkaniem osób, czego podstawą jest egzystencjalna komunikacja zachodząca pomiędzy ,ja”

\footnotetext{
87 V. E. Frankl, Psychotherapy and Existentialism. Selected Papers on Logotherapy, dz. cyt., s. 78.

${ }_{88}$ Tenże, Psychoterapia dla każdego, dz. cyt., s. 146.

89 Tenże, Nieuświadomiony Bóg, dz. cyt., s. 150-151.

90 V. E. Frankl, Psychotherapy and Existentialism. Selected Papers on Logotherapy, dz. cyt., s. $78-79$.
} 
i „ty"91. Jeżeli nie uda się takiej autentycznej relacji ustanowić, to same techniki terapeutyczne raczej nie przyniosą długotrwałego skutku ${ }^{92}$. Co prawda można wyuczyć człowieka - niczym zwierzę - nowych sposobów zachowania się, pożądanych reakcji na pewne typy oddziałujących na niego bodźców, jak to ma miejsce $\mathrm{w}$ behawioryzmie ${ }^{93}$. Taki trening nie będzie jednak niczym więcej niż „tresurą” i nie dotknie o wiele istotniejszego dla człowieka aspektu, nie wpłynie na jego sposób „bycia” jako osoby ${ }^{94}$. Zmiana w osobowym rdzeniu „bycia” dokonuje się dzięki obcowaniu z osobą, przez apel osoby-psychoterapeuty do osoby-pacjenta ${ }^{95}$. Odwołanie się do osobowej płaszczyzny bytowania człowieka oznacza, że można do terapii włączyć zasoby, którymi dysponuje pacjent jako osoba, czyli autotranscendencję, wolność, odpowiedzialność, odniesienie do obiektywnie istniejących sensu i wartości ${ }^{96}$.

\section{Wychowanie w logoterapii jako, „wychowywanie siebie”}

Frankl, jak się zdaje, rozumie wychowanie jako ,wychowywanie siebie"97. Takie podejście opiera się na jego przekonaniu o zdolnosci człowieka do zmiany, jego wolnej woli, która wyraża się, m.in. w niezależności duchowego wymiaru jednostki ludzkiej od biologiczno-psychicznych ograniczeń; w jego duchowej autonomii ${ }^{98}$. Człowiek może się zmieniać, ponieważ przekracza siebie: wykracza poza to, co immanentne, w kierunku tego, co transcendentne, a to dokonuje się dzięki jego otwartości

\footnotetext{
$91 \quad$ Tamże, s. 78.

92 Tenże, Das Menschenbild der Seelenheilkunde. Drei Vorlesungen zur Kritik des dynamischen Psychologismus, dz. cyt., s. 25.

93 Por. E. Lukas, The Logotherapy view of Human Nature, „, The International Forum for Logotherapy: Journal of Research for Meaning" 1980, No. 3/2, s. 11.

94 V. E. Frank1, Psychotherapy on its Way to Rehumanism, „,The International Forum for Logotherapy: Journal of Research for Meaning" 1980, No. 3/2, s. 6.

95 T. Gadacz, Wychowanie jako spotkanie osób, dz. cyt., s. 67.

96 V. E. Frankl, Psychotherapy on its Way to Rehumanism, dz. cyt., s. 4.

97 Por. H. Gall, Ein praktikables Psychotherapiekonzept für die Allgemeinpraxis, w: A. Längle (Hrsg.), Wege zum Sinn. Logotherapie als Orientierungshilfe, Piper, München-Zürich 1985, s. 145.

98 Tenże, The Unheard Cry for Meaning. Psychotherapy and Humanism, dz. cyt., s. 52-56, 69.
} 
na świat ${ }^{99}$. Wydobywanie $\mathrm{z}$ siebie różnych zdolności wymaga wpierw od człowieka wiary w ich istnienie ${ }^{100}$. Nie wiąże się to jednak z nieugruntowaną w rzeczywistości naiwną wiarą w nieograniczone możliwości ludzkie. Wolna wola jest wiązana odpowiedzialnością, gdyby była całkowicie wolna „roztopiłaby się w pustce”101. Wola respektuje różne ograniczenia, które pojawiają się na poziomie biologiczno-psychicznym człowieka, jednocześnie respektuje ograniczenia ujawniające się w duchowym wymiarze, które należy rozumieć jako pojawiające się przed człowiekiem powinności do wypełnienia. Dzięki odpowiedzialności człowiek poddaje się w swojej wolności prawu. Odpowiedzialność, jak wskazuje Frankl, jest aktem wiązania wolności, łączącym osobę $\mathrm{z}$ wyższym porządkiem $\mathrm{w}$ formie prawa ${ }^{102}$.

Dzięki wolności i odpowiedzialności człowiek jest w stanie kształtować siebie. Ludzie czasami uciekają od odpowiedzialności za siebie, „zrzekają się" swojej wolności i odpowiedzialności w imię iluzorycznego poczucia bezpieczeństwa, które otrzymują od grupy społecznej lub jakiegoś autorytetu ${ }^{103}$. Im więcej wolności i odpowiedzialności, tym większy obszar niepewności, który poddaje ciągłemu testowi ludzką potrzebę bezpieczeństwa. To, co Frankl proponuje człowiekowi, to powrót do źródła jego człowieczeństwa, którego nie można utożsamić z poczuciem psychicznego komfortu, raczej wzywa do postawy „odpowiadania za siebie", do wykroczenia poza sferę przyjemności i bezpieczeństwa ${ }^{104}$. Wychowanie we Franklowskiej psychoterapii nie skupia się zatem tylko na przekazywaniu wiedzy ${ }^{105}$, chodzi również o pomoc psychoterapeuty w kształtowaniu wrażliwego sumienia pacjenta tak, aby był zdolny ,usłyszeć tkwiące w każdej sytuacji żądania. W czasach, gdy dziesięć przy-

\footnotetext{
$99 \quad$ Tamże.

100 Tamże, s. 30.

101 T. Ballauff, Freiheit und Verantwortung in der Erziehung, w: G. Leo (Hrsg.), Akten des XIV. Internationalen Kongresses für Philosophie, Wien, 2-9 September 1968, Bd. 5, Philosophische Anthropologie, Herder, Freiburg im Breisgau 1970, s. 182.

102 V. E. Frankl, Zeit und Verantwortung, dz. cyt., s. 50.

103 Tenże, Psychotherapy and Existentialism. Selected Papers on Logotherapy, dz. cyt., s. 20.

104 Tenże, Die Sinnfrage in der Psychotherapie, R. Pieper \& Co. Verlag, München 1981, s. 141.

105 Tenże, Nieuświadomiony Bóg, dz. cyt., s. 92.
} 
kazań straciło dla wielu na swej ważności, człowiek musi mieć możność usłyszenia dziesięciu tysięcy przykazań utajonych w dziesięciu tysiącach sytuacji, z jakimi styka się w życiu"106.

Logoterapeuta nigdy nie powinien pouczać pacjenta ${ }^{107}$. Paradoksalnie, Rollo May podejrzewa logoterapię właśnie o balansowanie na granicy autorytarianizmu ${ }^{108}$, na co Frankl odpowiada, że rolą logoterapeuty nie jest bycie kaznodzieją i wskazywanie, co powinno stanowić o sensie życia pacjenta, logoterapeuta nie „wypisuje” pacjentowi sensu na receptę ${ }^{109}$. Zadaniem religii jest zbawienie duszy, a zadaniem psychoterapii jest „podnoszenie na duchu” ${ }^{110}$. Franklowska psychoterapia opiera się na postawie neutralnej odnośnie do wartości ${ }^{111}$. Logoterapeuta nie może dostarczać pacjentowi gotowego sensu i wartości, nie chodzi tu jednak o zajęcie przez terapeutę postawy biernej, terapeuta pozostaje aktywny, jako ten, który nieustannie wzywa pacjenta do przyjęcia za siebie i swoje życie odpowiedzialności, apeluje stale do osobowego pierwiastka pacjenta, do jego sumienia ${ }^{112}$. W wychowaniu do odpowiedzialności logoterapeuta staje sie wychowawcą jako świadek i jako towarzysz osobowego dojrzewania pacjenta. Frankl wskazuje, że logoterapeuta ,podprowadza” pacjenta tylko do punktu, w którym jest on w stanie samodzielnie i odpowiedzialnie decydować o sobie ${ }^{113}$.

Dienelt upatruje wychowawczą rolę logoterapeuty w budzeniu postawy odpowiedzialności u pacjenta ${ }^{114}$. Funkcją logoterapeuty jest bycie „katalizatorem"115: pomaganie pacjentowi w ujrzeniu drogi, która rozpoście-

\footnotetext{
106 Tamże.

107 Tenże, Der Wille zum Sinn. Ausgewählte Vorträge über Logotherapie, Verlag Hans Huber, Bern-Stuttgart-Wien 1972, s. 28.

108 R. May (ed.), Existential Psychology, Random House, New York 1961, s. 42.

109 V. E. Frankl, Nieuświadomiony Bóg, dz. cyt., s. 86.

110 Tamże, s. 86.

111 Tamże, s. 77.

112 Tenże, Psychoterapia dla każdego, dz. cyt., s. 153-154.

113 Tenże, Der Wille zum Sinn. Ausgewählte Vorträge über Logotherapie, dz. cyt., s. 43.

114 K. Dienelt, Erziehung zur Verantwortlichkeit. Die Existenzanalyse V. E. Frankls und ihre Bedeutung für die Erziehung, dz. cyt., s. 33.

115 V. E. Frankl, The Will to Meaning. Foundations and Applications of Logotherapy, dz. cyt., s. 45 .
} 
ra się przed nim, bez „,popychania” czy „ciągnięcia” go za sobą. Aby to uczynić, logoterapeuta stosuje techniki takie jak derefleksja, paradoksalna intencja, ale również wychowawczą wartość pełni osobisty przykład, jaki daje psychoterapeuta: „Nie możemy nauczać o wartościach - musimy nimi żyć"116. Logoterapeuta nie może oddzielić swojego osobistego życia, swoich osobistych wyborów od praktyki logoterapeutycznej: musi żyć logoterapią, przez podążanie za jej ideami, tak aby stać się osobowym wzorcem do naśladowania dla pacjenta ${ }^{117}$, jednak nie w tym znaczeniu, jakie konkretne wartości należy realizować, lecz przez sposób, w jaki akceptuje się odpowiedzialność za swoje wybory. Chodzi o osobową podstawę tych wyborów, która wyraża się w wolności i odpowiedzialności ${ }^{118}$. Wychowanie w logoterapeutycznym sensie: ,jest darowaniem nie sensu, ale raczej przykładu, osobistego przykładu i oddania na drodze poszukiwania (...) prawdy"119. Autorytarne podejście logoterapeuty byłoby zatem zaprzeczaniem idei odpowiedzialności, do której Frankl odwołuje się w swoich rozważaniach.

„Człowiek nie lubi być pouczany”120, wskazuje Frankl. Pouczanie może prowadzić do negatywnej reakcji, co - zdaniem Bubera-może wywołać efekt przeciwny do zamierzonego przez wychowawcę, efekt buntu pacjenta $^{121}$. Wychowanie będzie raczej polegało na „otwieraniu” umysłu człowieka na sens ukryty w każdej życiowej sytuacji, kształtowaniu w pacjencie umiejętności rozpoznawania sensu i jego realizacji ${ }^{122}$. Logoterapeuta jest również wezwany do tego, aby wychowywać siebie, jako

\footnotetext{
116 Tenże, Der Wille zum Sinn. Ausgewählte Vorträge über Logotherapie, dz. cyt., s. 28.

117 Por. B. Wicki, Die Existenzanalyse von Viktor E. Frankl als Beitrag zu einer anthropologisch fundierten Pädagogik, dz. cyt., s. 245-248.

118 F. Schlederer, Erziehung zu personaler Existenz. Viktor E. Frankl's Existenzanalyse und Logotherapie als Beitrag zu einer anthropologisch fundierten Pädagogik, dz. cyt., s. 3.

119 V. E. Frankl, The Will to Meaning. Foundations and Applications of Logotherapy, dz. cyt., s. 87.

120 Tenże, Die Sinnfrage in der Psychotherapie, dz. cyt., s. 85.

121 M. Buber, Reden über Erziehung, Lambert Schneider, Heidelberg 1969, s. 55.

122 B. Wicki, Erziehung im Spannungsfeld von Intention und Wirkung, w: A. Längle (Hrsg.), Wege zum Sinn. Logotherapie als Orientierungshilfe, Piper, München-Zürich 1985, s. 182.
} 
jednostka ludzka znajduje się w ciągłym procesie samo-wychowywania, tego, co Buber określa „samo-wychowaniem wychowawcy" ${ }^{23}$.

Wicki jest przekonany, że wychowanie jest dwukierunkowym procesem między logoterapeutą a pacjentem, jest ciągłym procesem uczenia się, jak być odpowiedzialnym ${ }^{124}$. Paradoksalnie, w logoterapii może dojść do odwrócenia ról, kiedy to pacjent staje się dla psychoterapeuty wychowawcą, a psychoterapeuta staje się uczniem pacjenta. Chodzi tu zwłaszcza o sytuację cierpienia, kiedy pacjent przez swoje doświadczenia uczy swojego terapeutę, jak zmagać się z nieuniknionym ludzkim losem ${ }^{125}$. Dzielne znoszenie różnych dolegliwości wypływających z choroby może być formą świadectwa dawanego przez pacjenta, co może wychowawczo oddziaływać na psychoterapeutę.

Frankl wskazuje, że człowiek na drodze poszukiwania swojego życiowego sensu do wypełnienia może z jakiś powodów się zagubić, dlatego czasami w swoim postępowaniu potrzebuje przewodnika - logoterapeuty ${ }^{126}$. Kto jednak myśli, że życie sensowne utożsamia się z życiem szczęśliwym, przyjemnym, łatwiejszym, będzie głęboko zawiedziony przesłaniem logoterapii. Typowe cele wychowania do życia szczęśliwego, pełnego sukcesu, prowadzącego do samorealizacji siebie nie są przedmiotem zainteresowania logoterapeutycznego wychowania, jeżeli się już one pojawiają to jako skutki uboczne dążenia do sensu. Wszystkie te fenomeny koncentrują się wokół „,ja”, podczas gdy logoterapia zaprasza człowieka do transcendowania siebie. Człowiek nie jest w stanie stać się w pełni osobą bez sięgania poza siebie. Nie dzieje się to bez pewnej dozy stresu i nie obywa się to bez pewnego stanu wewnętrznego napięcia, ale nie powinno się tego unikać. Zmaganie się z sensem i wartościami, chociaż czasami nie odbywa się bez psychicznego bólu, jest tak naprawdę sygnałem zdrowia psychicznego. W tym sensie spokój wewnętrzny, spokój sumienia nie będzie również nigdy pomyślany jako cel logoterapii.

\footnotetext{
123 M. Buber, Wychowanie, dz. cyt., s. 460.

124 Tamże.

125 V. E. Frankl, Nieuświadomiony Bóg, dz. cyt., s. 160.

126 Tenże, Homo patiens, dz. cyt., s. 44.
} 


\section{Zakończenie}

Frankl stosuje rozróżnienie pomiędzy ,życiem pełnym sensu”, a „życiem pełnym sukcesu". Tych kategorii nie powinno się ani przeciwstawiać, ani do siebie sprowadzać. „Życie pełne sensu” może dokonywać się zarówno w ,życiu pełnym sukcesu”, jak i „w życiowym niepowodzeniu”. Dążenie do sensu wykracza poza pojęcie samorealizacji. Realizowanie siebie - czy to przez dążenie do szczęścia, czy przez poszukiwanie przyjemności - zamyka ostatecznie człowieka w kręgu własnego ,ja”, czyni z niego „monadę”. A tak naprawdę, jak podkreśla Frankl, człowiek jest bytem „otwartym ku” światu sensu i wartości, które może realizować dzięki autotranscendencji, zdolności do wykraczania „poza siebie”. Dopiero kiedy człowiek transcenduje swoje ,ja”, może spotkać drugą osobę.

Ukierunkowanie człowieka na świat sensu i wartości jest podstawą Franklowskiego systemu psychoterapeutycznego. Logoterapia jest wychowaniem pacjenta ku życiu pełnego sensu dzięki przyjęciu przez niego postawy odpowiedzialności. Logoterapeuta jest rozumiany jako przewodnik, nie dostarcza on jednak pacjentowi sensu, zakłada, że każda jednostka ludzka jest w stanie odszukać sens samodzielnie, raczej subtelnie wspomaga pacjenta $\mathrm{w}$ procesie tego poszukiwania za pomocą rozmaitych technik. Proces wychowawczy logoterapeuty odnosi sie do zaoferowania siebie jako przykładu, dlatego Frankl domaga sie od logoterapeutów, aby sami również żyli ideami logoterapeutycznymi nie tylko w życiu zawodowym, lecz także prywatnym. W tym sensie logoterapeuta jest wezwany, aby wychowywać sam siebie. Logoterapeuta powinien budzić odpowiedzialność pacjenta, tak żeby mógł słuchać swojego sumienia, kiedy dokonuje wyboru odnośnie do sensu i wartości. Tylko pacjent może wprowadzać zmiany w swoim życiu, które będą sięgać samego rdzenia jego osobowego bytu, tego nie może za niego dokonać logoterapeuta ${ }^{127}$.

\section{Bibliografia}

Ballauff T., Freiheit und Verantwortung in der Erziehung, w: G. Leo (Hrsg.), Akten des XIV. Internationalen Kongresses für Philosophie,

127 Tenże, Anthropologische Grundlagen der Psychotherapie, dz. cyt., s. 312. 
Wien, 2-9 September 1968, Bd. 5, Philosophische Anthropologie, Herder, Freiburg im Breisgau 1970, s. 181-187.

Buber M., Reden über Erziehung, Lambert Schneider, Heidelberg 1969. Buber M., Wychowanie, „Znak” 1968, nr 166, s. 442-461.

Chudy W., Prawda człowieka i prawda o człowieku, w: K. Popielski (red.), Człowiek-wartości-sens. Studia z psychologii egzystencji. Logoteoria i nooteoria. Logoterapia i nooterapia, Redakcja Wydawnictw Katolickiego Uniwersytetu Lubelskiego, Lublin 1996, s. 129-148.

Dienelt K., Die anthropologischen Grundlagen der Pädagogik. Konstruktiv-analytische Reflexionen zum Thema „Pädagogische Anthropologie”, A. Henn Verlag, Kastellaun-Düsseldorf 1977.

Dienelt K., Erziehung zur Verantwortlichkeit. Die Existenzanalyse V. E. Frankls und ihre Bedeutung für die Erziehung, Österreichischer Bundesverlag, Wien 1955.

Fizzotti E., La logoterapia di Frankl. Un antidoto alla disumanizzazione psicanalitica, Rizzoli, Milano 1974.

Frank1 V. E., Das Menschenbild der Seelenheilkunde. Kritik des dynamischen Psychologismus, Hippokrates Verlag, Stuttgart 1959.

Frankl V. E., Der leidende Mensch. Anthropologische Grundlagen der Psychotherapie, Hans Huber, Bern 1975.

Frankl V. E., Der Mensch vor der Frage nach dem Sinn. Eine Auswahl aus dem Gesamtwerk, Piper, München-Zürich 1995.

Frankl V. E., Der Wille zum Sinn. Ausgewählte Vorträge über Logotherapie, Verlag Hans Huber, Bern-Stuttgart-Wien 1972.

Frank1 V. E., Die Sinnfrage in der Psychotherapie, R. Pieper \& Co. Verlag, München 1981.

Frankl V. E., Homo patiens, Instytut Wydawniczy PAX, Warszawa 1984. Frankl V. E., Nieuświadomiony Bóg, Instytut Wydawniczy PAX, Warszawa 1978.

Frankl V. E., Man's Search for Meaning. An Introduction to Logotherapy, Washington Square Press, New York 1964.

Frankl V. E., Psychoterapia dla każdego, Instytut Wydawniczy PAX, Warszawa 1978. 
Frankl V. E., Psychotherapy and Existentialism. Selected Papers on Logotherapy, Souvenir Press, London 1970.

Frankl V. E., Psychotherapy on its Way to Rehumanism, "The International Forum for Logotherapy: Journal of Reaserch for Meaning" 1980, No. 3/2, s. 3-9.

Frankl V. E., The Unheard Cry for Meaning. Psychotherapy and Humanism, A Touchstone Book, New York 1979.

Frankl V. E., The Will to Meaning. Foundations and Applications of Logotherapy, New America Library, New York-London-Scarborough, Ontario 1970.

Frankl V. E., Was nicht in meinen Büchern steht, Quintessenz MMV Medizin Verlag, München 1995.

Frankl V. E., Zeit und Verantwortung, Franz Deuticke, Wien 1947.

Gadacz T., Wychowanie jako spotkanie osób, „Znak” 1991, nr 436, s. 6268.

Gall H., Ein praktikables Psychotherapiekonzept für die Allgemeinpraxis, w: A. Längle (Hrsg.), Wege zum Sinn. Logotherapie als Orientierungshilfe, Piper, München-Zürich 1985, s. 142-147.

Kukułowicz T., Wartości w wychowaniu, w: K. Popielski (red.), Człowiek-wartości-sens. Studia z psychologii egzystencji. Logoteoria i nooteoria. Logoterapia $i$ nooterapia, Redakcja Wydawnictw Katolickiego Uniwersytetu Lubelskiego, Lublin 1996, s. 411-414.

Längle A., Orientierung am Sinn. Die unbedingte Suche nach Sinn, w: tegoż (Hrsg.), Wege zum Sinn. Logotherapie als Orientierungshilfe, Piper, München-Zürich 1985, s. 82-90.

Lukas E., Ein psychiatrisches und ein psychotherapeutisches Credo, w: D. Batthyány, O. Zsok (Hrsg.), Viktor Frankl und die Philosophie, Springer Verlag, Vienna 2005, s. 13-22.

Lukas E., The Logotherapy view of Human Nature, „The International Forum for Logotherapy: Journal of Reaserch for Meaning" 1980, No. $3 / 2$, s. $10-13$.

Marcel G., Być i mieć, Instytut Wydawniczy PAX, Warszawa 1986.

May R. (ed.), Existential Psychology, Random House, New York 1961. 
Michalski J. T., Sens życia a pedagogika. Impulsyżycia V. E. Frankla, Wydawnictwo Naukowe Uniwersytetu Mikołaja Kopernika, Toruń 2011. Nanni C., Educazione e scienze dell'educazione, LAS, Roma 1986.

Nowak M., Znaczenie wartości w procesie wychowania, w: K. Popielski (red.), Człowiek-wartości-sens. Studia z psychologii egzystencji. Logoteoria i nooteoria. Logoterapia i nooterapia, Redakcja Wydawnictw Katolickiego Uniwersytetu Lubelskiego, Lublin 1996, s. 241-259.

Popielski K. (red.), Człowiek-wartości-sens. Studia z psychologii egzystencji. Logoteoria i nooteoria. Logoterapia i nooterapia, Redakcja Wydawnictw Katolickiego Uniwersytetu Lubelskiego, Lublin 1996.

Popielski K., Psychologia egzystencji. Wartości w życiu człowieka, Wydawnictwo Katolickiego Uniwersytetu Lubelskiego, Lublin 2008.

Schlederer F., Erziehung zu personaler Existenz. Viktor E. Frankl's Existenzanalyse und Logotherapie als Beitrag zu einer anthropologisch fundierten Pädagogik, Inaugural-Dissertation, München 1964.

Szostek A., Człowiek-wartości-sens. Przemówienie na otwarcie IV Ogólnopolskiego Sympozjum Logoterapii w: K. Popielski (red.), Człowiek-wartości-sens. Studia z psychologii egzystencji. Logoteoria $i$ nooteoria. Logoterapia $i$ nooterapia, Redakcja Wydawnictw Katolickiego Uniwersytetu Lubelskiego, Lublin 1996, s. 11-13.

Trzópek J., Problem woli. Między antropologia filozoficzna a psychologia mechanizmów regulacyjnych, Towarzystwo Naukowe Societas Vistulana, Kraków 2003.

Wolicki M., Otwartość osoby ludzkiej. Interpretacja filozoficzna, Papieski Wydział Teologiczny we Wrocławiu, Wrocław 2005.

Waibel E. M., Erziehung zum Sinn - Sinn der Erziehung. Grundlagen einer existenziellen Pädagogik, Brigg Pädagogik Verlag, Augsburg 2011.

Wicki B., Die Existenzanalyse von Viktor E. Frankl als Beitrag zu einer anthropologisch fundierten Pädagogik, Verlag Paul Haupt, BernStuttgart 1991.

Wicki B., Erziehung im Spannungsfeld von Intention und Wirkung, w: A. Längle (Hrsg.), Wege zum Sinn. Logotherapie als Orientierungshilfe, Piper, München-Zürich 1985, s. 168-185. 


\section{Summary}

Viktor Emil Frankl is the founder of the Third Viennese School of Psychotherapy, a psychotherapeutic approach combining in a new way psychological results with philosophical analysis. An important aspect of Frankl's psychotherapeutic program is education, which in his approach should focus on the categories of responsibility, meaning, and values.

Key words: Viktor Emil Frankl, Third Viennese School of Psychotherapy, logotherapy, logotheory, education, responsibility, meaning, values. 
